\title{
INTELLIGENS ROBOTMEGFOGÓ FEJLESZTÉSE
}

\author{
Rónai László \\ doktorandusz, Miskolci Egyetem, Szerszámgépészeti és Mechatronikai Intézet, \\ Robert Bosch Mechatronikai Intézeti Tanszék \\ 3515 Miskolc,Miskolc-Egyetemváros, e-mail: ronai.laszlo@uni-miskolc.hu \\ Szabó Tamás \\ egyetemi docens, Miskolci Egyetem, Szerszámgépészeti és Mechatronikai Intézet, \\ Robert Bosch Mechatronikai Intézeti Tanszék \\ 3515 Miskolc, Miskolc-Egyetemváros, e-mail: szabo.tamas@uni-miskolc.hu
}

\begin{abstract}
Absztrakt
A cikk egy olyan intelligens robotmegfogó fejlesztésének lépéseit ismerteti, amelyet különbözö, stabilitásvesztéssel járó szerelési folyamatokra lehet alkalmazni. A megfogó két részböl tevödik össze, az elsö egy pneumatikusan mozgatott munkadarabok megfogására alkalmas kereskedelemben kapható mechanizmus, mig a második része egy egyedileg tervezett, mikrovezérlöt és egy erömérö cellát tartalmazó egység. A megtervezett és megépitett robotmegfogó intelligens alkalmazására a cikk egy akkumulátorpakk feltöltési folyamatát mutatja be.
\end{abstract}

Kulcsszavak: robotmegfogó, Arduino, erömérö cella

\begin{abstract}
This paper is dealt with a development of an intelligent robotic end-effector, which is capable to use assembly tasks involving the loss of stability. The end-effector contains two main parts, the first is a commercially made pneumatic gripper, which can be used to grip and manipulate objects. The second part of the system is uniquely developed, and it contains a microcontroller and a load cell. In order to demonstrate the applicability of the designed and manufactured end-effector the assembling process of a battery pack is described in this paper.
\end{abstract}

Keywords: robotic end-effector, Arduino, load cell

\section{Bevezetés}

Napjainkban a robotok különböző folyamatokra történő alkalmazása az Ipar 4.0 törekvésnek [1] köszönhetően is előtérbe került. A koncepció lehetővé teszi a rugalmas tömeggyártás feltételeinek megteremtését. Az emberi erő és intelligencia kiváltása megköveteli a gyártási folyamatok újragondolását, tervezését. A különböző értékteremtő folyamatok távoli eléréssel monitorozhatóvá, illetve irányíthatóvá válnak.

A robotok kiváltják az olyan, ember által végzett folyamatokat, amelyek általában monoton-, nehéz fizikai munkát jelentenek. Az iparban alkalmazott robotok nagy része pozícióvezérléssel rendelkezik, emiatt pl. különböző szerelési folyamatok elvégzésekor túlterhelés léphet fel a termék és a robot szempontjából is. A heptikus visszacsatolást [2] a kereskedelemben kapható robotok többnyire nem tartalmazzák, viszont az emberi munkaerő kiváltásánál ez nélkülözhetetlen a robotizált szerelési fo- 
lyamatok végrehajtásánál [3]. A piacon kaphatók olyan robotmegfogók, amelyek tartalmaznak erőmérő cellákat, ezzel kiegészítve a rendszert erővisszacsatolással. Az ilyen megfogók relative drágák és nem programozhatók szabadon pl. stabilitásvesztéssel járó folyamatok detektálására. Az erőmérő cellák ipari robothoz illeszthetők, amelyekkel erő-visszacsatolás valósítható meg, így a folyamatok során fellépő erők kihathatnak a müködésre [4].

Már az ezredforduló idején megalkottak olyan robotos összeszerelő rendszereket, amelyek mellett megjelentek az erőmérö rendszerek és képfeldolgozó eszközök is, mint visszacsatolást adó elemek [5]. Egyedileg fejlesztett intelligens robotmegfogókról készült cikkeket lehet találni több folyóiratban is. A [6] irodalom egy olyan robotmegfogó koncepció megalkotását tűzte ki célul, amellyel az eddig emberi munkaerővel történő szerelési folyamatok automatizálásánál jól alkalmazható lenne.

A további fejezetek egy olyan intelligens robotmegfogó fejlesztését mutatják be, amelyet különböző szerelési folyamatokra lehet használni. A rendszer lehetővé teszi a folyamat közbeni erőmérést, valamint az erőértékek megjelenítését személyi számítógépen.

A cikk a fejlesztést lépéseit a következő két fejezetekben ismerteti. A második fejezet tartalmazza az intelligens robotmegfogó tervezési követelményeit, majd bemutatja az egység modellezését és kitér annak gyártására és összeépítésére. A harmadik fejezet tartalmazza az összeállított rendszer teszt müködése során kapott eredményeket, megállapításokat. Az összefoglalás részletezi a fejlesztés során elért eredményeket és kitér a robotmegfogó jövőben történő alkalmazási lehetőségeire.

\section{A megfogó tervezése és gyártása}

A fejezet tartalmazza azokat a szempontokat, amelyeket a tervezés során figyelembe kellett venni. A fejlesztési folyamat kitér az alkatrészek tervezésére, gyártására és összeszerelésére.

\subsection{Tervezési követelmények megfogalmazása}

A megfogóval szemben támasztott követelményeket két fő részre lehet bontani, az első a hardveres-, a második a szoftveres követelmények csoportja. A hardver szintü követelmények:

- biztosítsa a szerelés irányú erőmérést;

- védje a berendezést a túlterheléstől;

- kínáljon megoldást a robottal történő kommunikációra;

- legyen könnyü és kompakt;

- legyen könnyen szerelhető kivitelü.

A csak szerelés irányú erőmérést két párhuzamos, lemezek alkotta rugalmas mechanizmus fogja biztosítani, amelyet [7] részletesen bemutat. A túlterhelési védelem az erőmérő cella maradó alakváltozását hivatott meggátolni, amelyet hernyócsavarok biztosítanak (lásd: 3. ábra). A könnyü szerelhetőség és a kompakt kiszerelés egymásnak ellentmondó követelmények, amelyekre a modellezés során mindig tekintettel kell lenni.

A robottal történő kommunikáció kiépítéséhez biztosítani kell a feszültségszintek közötti különbség áthidalását, amelyet a mikrovezérlő ki- és bemenetei, valamint a robot ki- és bemenetei között elhelyezett optocsatolókkal valósítunk meg. 
A szoftveres követelmények:

- programozható legyen különböző feladatokra;

- $\quad$ szerelés közben fellépő stabilitásvesztéssel járó erőlefutás jellemző pontjainak detektálása;

- a szerelés monitorozása, az erőértékek lementése központi számítógépre;

- információcsere a robottal.

A megfogó programozhatóságát egy Arduino fejlesztő platform biztosítja. A stabilitásvesztést jellemző feltételrendszer alkalmazásával a program képes meghatározni a megfogó nyitását-, valamint üzenetet küldeni a robotnak. A robot szerelés közbeni mozgásakor fellépő erők függvényében a rendszernek be kell tudni avatkoznia, ha a folyamat kiugró erő-elmozdulással jár. A mikrovezérlő az erőértékeket a személyi számítógép számára UART kommunikációs protokollal továbbítja.

\subsection{A megfogó tervezése}

A megfogó geometriai modellezésére a Robert Bosch Mechatronikai Intézeti Tanszéken az Autodesk Inventor szoftver állt rendelkezésünkre. A megfogó összesen 19 tervezendő alkatrészből áll. Terjedelmi okok miatt a cikk csak a múködés szempontjából fontos túlterhelésvédelmet biztosító alumínium alkatrész mühelyrajzát mutatja (lásd: 1. ábra). Az M4 furatokban hernyócsavarok fogják megakadályozni az erőmérő cella túlterhelését. Az egység rögzítését a megfogóhoz két M5 csavar biztosítja.

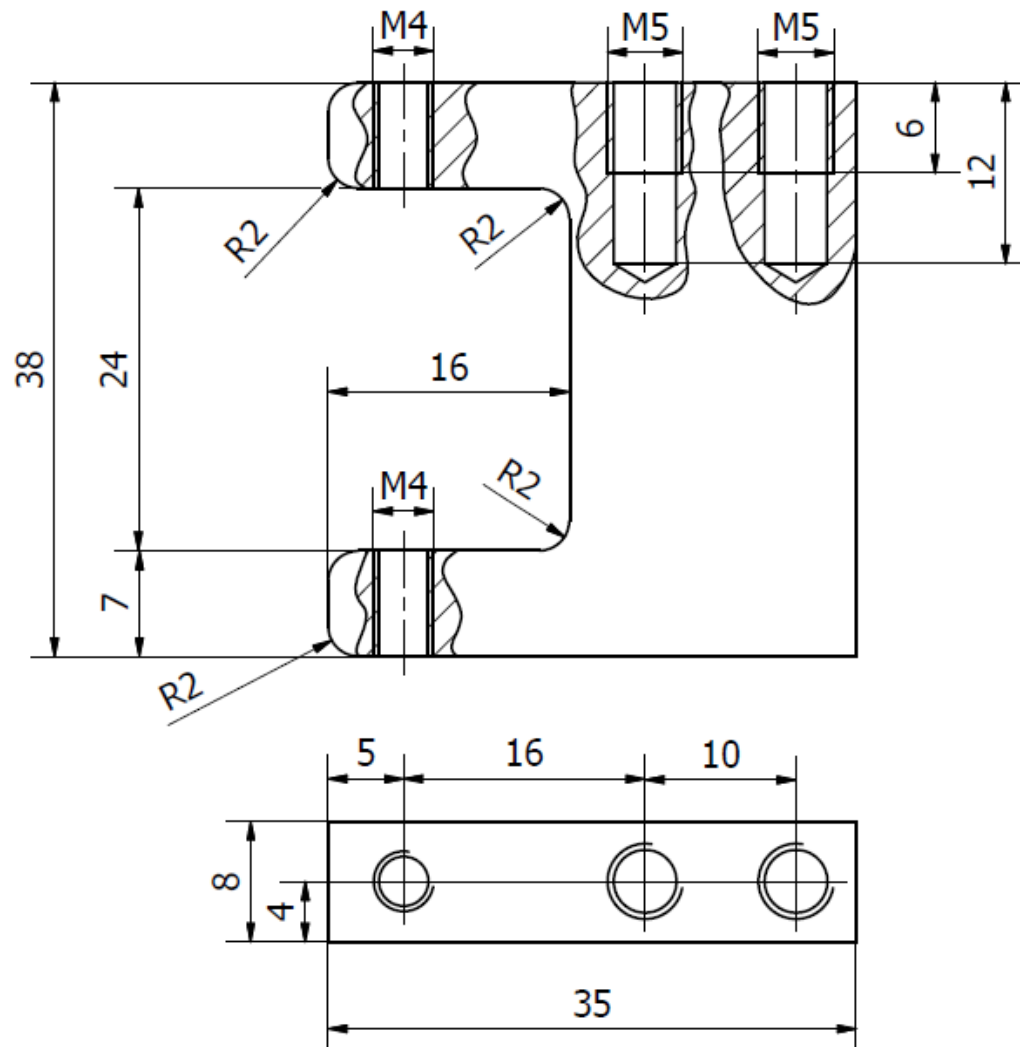

1. ábra. A túlterhelésvédelem alkatrészrajza 


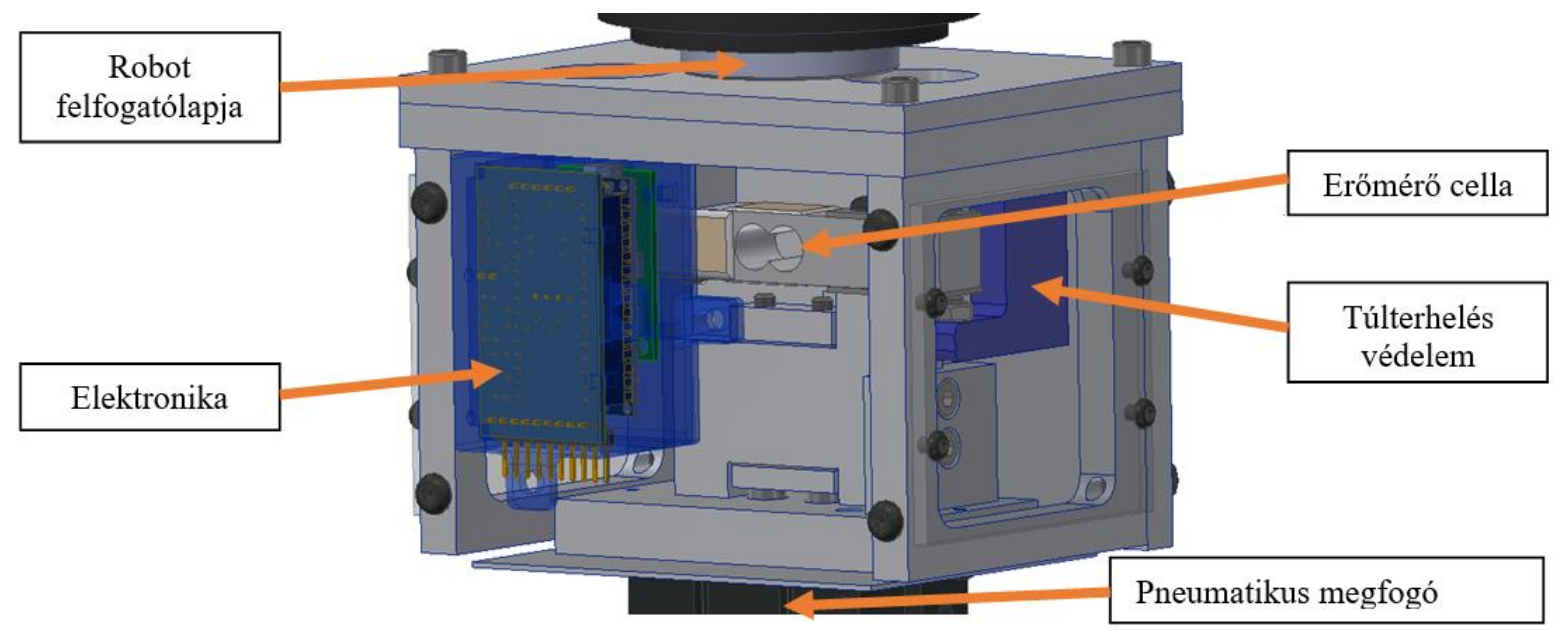

2. ábra. A megfogó 3D-s modellje

Az elkészült 3D-s modellt a fóbb részeivel a 2. ábra szemlélteti. Az egyik központi eleme egy erömérő cella, amelynek a terhelhetősége $200 \mathrm{~N}$. A másik pedig az intelligenciát biztosító elektronika. Egy hagyományos pneumatikus megfogó található a berendezés aljához rögzítve.

\subsection{A megfogó gyártása és összeépítése}

A megtervezett alkatrészek a Szerszámgépek Intézeti Tanszéke-, valamint az Anyagszerkezettani és Anyagtechnológiai Intézet mühelyében készültek el CNC megmunkáló központon és hagyományos szerszámgépeken.

Az 1. ábrán megtervezett villa alakú túlterhelési védelmet biztosító legyártott alkatrészt a 3 . ábra mutatja a hernyócsavarokkal. Ezek állításával határolható le az erőmérő cella terhelése. A hernyócsavarok a méröcella szabad végén, az átellenes oldalain található acéllemezeken keresztül ütközik fel.

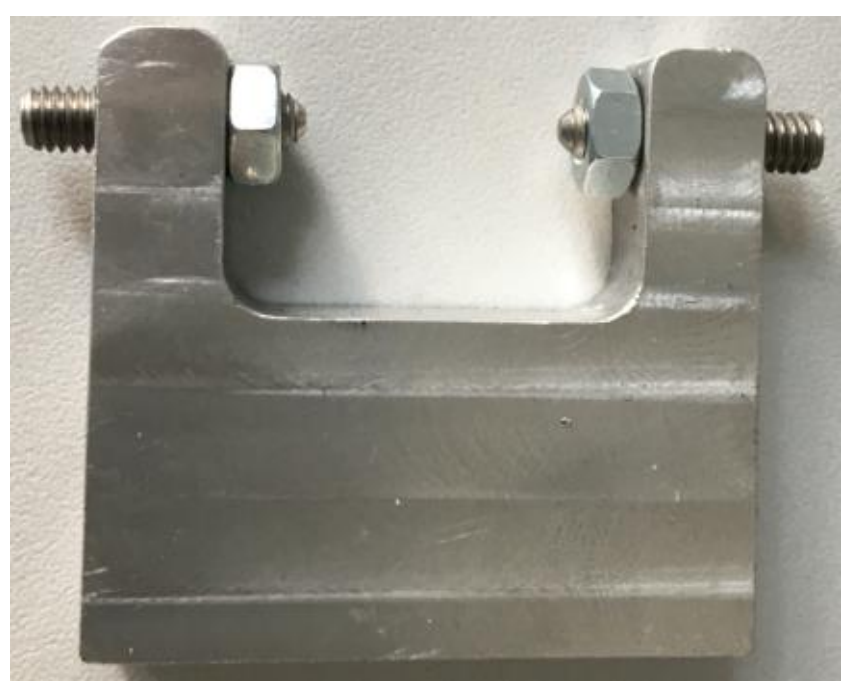

3. ábra. A túlterhelési védelmet biztositó alkatrész 
A megfelelő alumínium alkatrészek összeszerelése, erőmérő cella beépítése, elektronika elhelyezése és a pneumatikus megfogó rögzítése után elkészült intelligens megfogót a 4. ábra szemlélteti a fedél kivételével. A túlterhelési védelem a megfogó fedeléhez van csavarozva, így ezen az ábrán az sem látható.

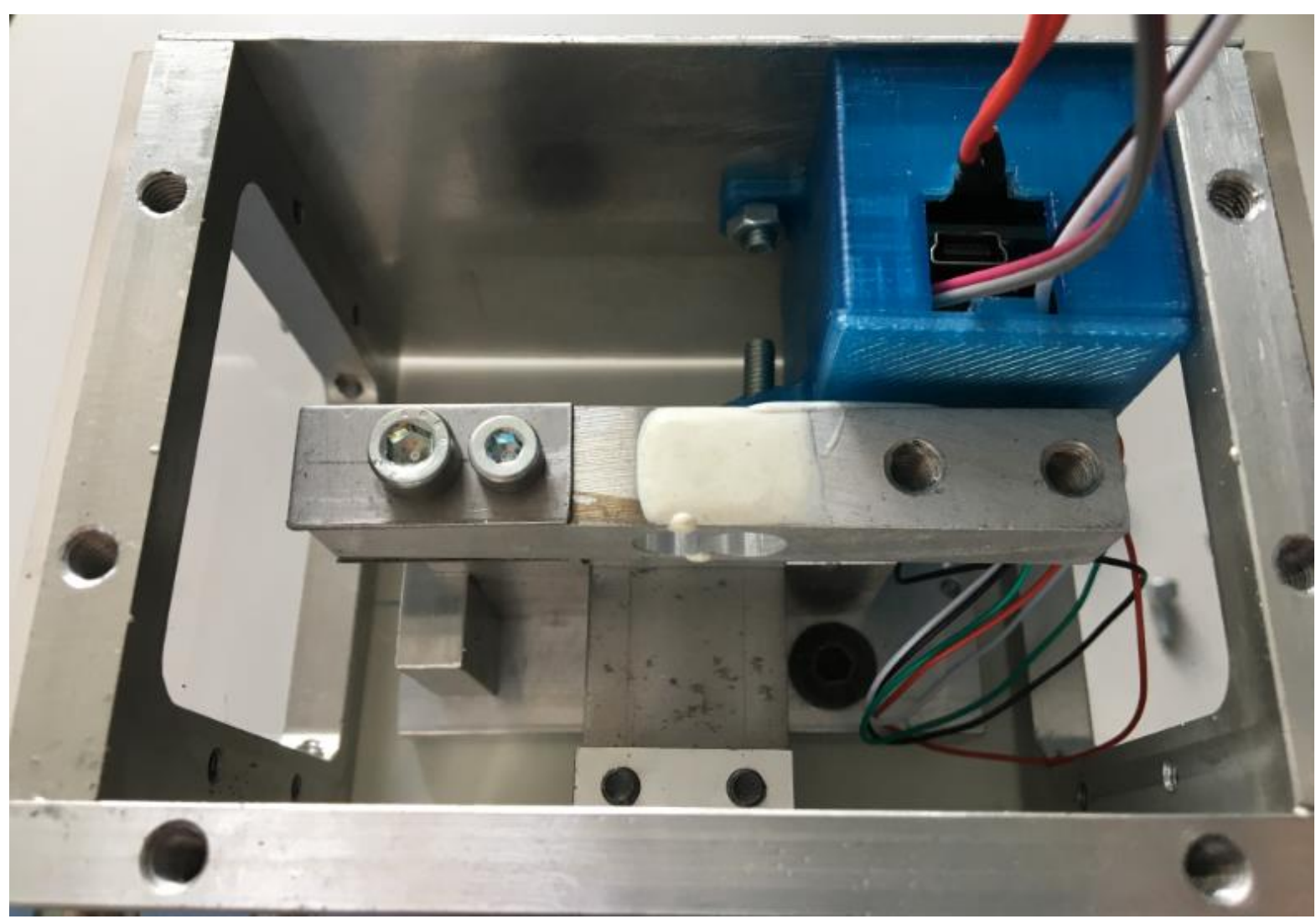

4. ábra. A megépitett megfogó felülnézetböl

\section{Megfogó tesztelése}

Az elkészült megfogó egy Fanuc LR Mate 200iC 6 szabadsági fokkal rendelkező ipari robotra történt a felszerelése. A tesztmérés kiértékelésére egy LabVIEW program került kifejlesztésre, amely a szerelés során fellépő eröt közel valós időben szemlélteti. A program a mért eredményt további kiértékelés céljából táblázatosan is lementi.

A tesztmérés során egy müanyag cellatartóba a robot 5 lítium-ion akkumulátort helyez be. A feladatspecifikus feltételrendszer beprogramozása után a szerelés során mért erőértékeket az 5 . ábra mutatja. Az első három egymással nem szomszédos cella behelyezése közel azonos erőszükségletet igényelt, viszont a további kettőnél már a szomszédos bent lévő cellák miatt többszörösére nőtt a beszerelési erő. A próbafutás eredményesen zárult, hiszen az intelligens megfogó minden esetben a stabilitásvesztéskor elengedte a cellákat. 


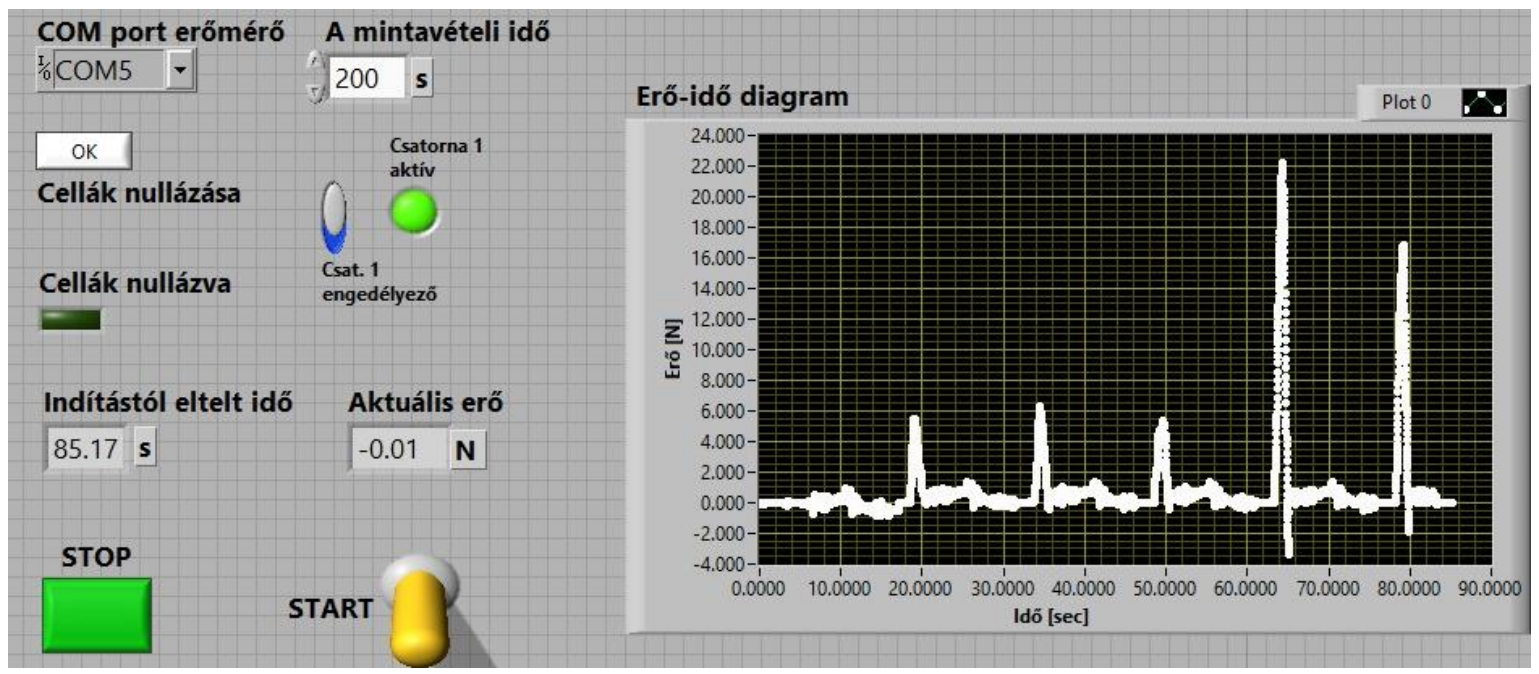

5. ábra. A számitógépes grafikus felülete az erömérésnek

\section{4. Összefoglalás}

A cikk egy intelligens robotmegfogó fejlesztését ismertette, amelyet szerelés közbeni stabilitásvesztéssel járó folyamatoknál lehet alkalmazni olyan ipari robotok esetében, amelyek eredetileg csak pozícióvezérléssel rendelkeznek. A szerelés közbeni erőmérés által lehetővé vált az erővisszacsatolás. Az alkalmazott mikrovezérlő döntést hoz a szerelési folyamat befejezésére, a megfogó nyitására, hogy a munkadarabot és a robotot ne érje túlterhelés. A tesztmérések eredményesen záródtak, az 5 darab akkumulátor szerelése közben mind magától bepattant a müanyag cellatartóba.

A jövőbeni tervek között szerepel a kifejlesztett rendszer további, stabilitásvesztéssel járó folyamatokra-, illetve minőségellenőrzési célokra történő alkalmazása.

\section{Köszönetnyilvánítás}

A cikkben ismertetett kutató munka az EFOP-3.6.1-16-2016-00011 jelü „Fiatalodó és Megújuló Egyetem - Innovatív Tudásváros - a Miskolci Egyetem intelligens szakosodást szolgáló intézményi fejlesztése" projekt részeként - a Széchenyi 2020 keretében - az Európai Unió támogatásával, az Európai Szociális Alap társfinanszírozásával valósul meg.

\section{Irodalomjegyzék}

[1] Rojko A.: Industry 4.0 Concept: Background and Overview, International Journal of Interactive Mobile Technologies, Vol. 11, No. 5, 2017, pp. 77-90. https://doi.org/10.3991/ijim.v11i5.7072

[2] Srinivasan M. A.: What is Haptics, Laboratory for Human and Machine Haptics, The Touch Lab MIT, 2005, pp. 1-11.

[3] Radi M., Reinhart G.: Industrial Haptic Robot Guidance System for Assembly Processes, IEEE Conference, Lecco, Italy, 2009, pp.1-6. https://doi.org/10.1109/HAVE.2009.5356135

[4] Loske J., Biesenbach R.: Force-torque sensor integration in industrial robot control, 15th In- 
ternational Workshop on Research and Education in Mechatronics, IEEE, El Gouna, Egypt, 2014, pp. 1-5. https://doi.org/10.1109/REM.2014.6920241

[5] Jörg S., Langwald J., Stelter J., Hirzinger G., Natale C.: Flexible Robot-Assembly using a Multi-Sensory Approach, IEEE International Conference on Robotics \& Automation, 2000, pp. 3687-3694

[6] Vittor T., Staab H., Breisch S., Soetebier S., Stahl T., Hackbarth A., Kock S.: A Flexible Robotic Gripper for Automation of Assembly Tasks, in Proc. IEEE Int. Symp. Assembly Manuf., 2011, pp. 1-6.

[7] Rónai L.: Design Aspects of a Robotic End-effector, Design of Machines and Structures, Vol. 8., No. 2, 2018, pp. 52-58. 